\title{
UJI AKTIVITAS EKSTRAK BUAH PARE (Momordica charantia L) TERHADAP PERTUMBUHAN Propionibacterium acnes
}

\author{
Dwi Rachmawaty Daswi ${ }^{1}$, Asmawati ${ }^{2}$ \\ 1,2 Jurusan Farmasi Poltekkes Kemenkes Makassar \\ *) dwialamsyah@gmail.com \\ *) asmaasmawati30@gmail.com
}

https://doi.org/10.32382/mf.v14i2.590

\begin{abstract}
ABSTRAK
Telah dilakukan penelitian tentang Uji Aktivitas Ekstrak Buah Pare (momordica charantia L.) terhadap pertumbuhan propionibacterium acnes yang bertujuan untuk menentukan aktivitas ekstrak buah pare (Momordica charntia L) terhadap pertumbuhan propionibacterium acnes. Diameter zona hambat rata-rata yang dihasilkan oleh sampel Ekstrak Buah Pare (Momordicacharantia L) dengan konsentrasi 2,5\% v/v adalah $11 \mathrm{~mm}$, konsentrasi $5 \% \mathrm{v} / \mathrm{v}$ adalah $12 \mathrm{~mm}$, dan konsentrasi 10\% v/v adalah 13mm dengan menggunakan $\odot \mathrm{Na} . \mathrm{CMC} 1 \%$ sebagai kontrol negatif sebesar $0 \mathrm{~mm}$ dan Clindamycin sebagai kontrol positif sebesar 27 mm. $\alpha<0,05$ menunjukan bahwa telah dilakukan pengujian SPSS dengan konsentrasi $2,5 \% \mathrm{v} / \mathrm{v}, 5 \% \mathrm{v} / \mathrm{v}, 10 \% \mathrm{v} / \mathrm{v}$ memiliki efek yang zona hambatnya berbeda. Berdasarkan hasil penelitian ini,maka dapat disimpulkan bahwa ekstrak buah pare memiliki daya hambat terhadap pertumbuhan Propionibacterim acnes secara optimal yaitu konsentrasi $10 \% \mathrm{v} / \mathrm{v}$, jadi semakin tinggi konsentrasi yang digunakan semakin luas pula zona hambatnya.
\end{abstract}

Kata kunci : Uji Aktivitas, Ekstrak Buah Pare, Propionibacterium acnes

\section{PENDAHULUAN}

Indonesia adalah Negara beriklim tropis, jenis kulit dan polusi udara menjadi salah satu penyebab jerawat. Jerawat atau acne vulgaris,biasa disebut acne, adalah penyakit kulit obstruktif dan inflamasi kronik pada pilosebasea yang sering terjadi pada masa remaja (Movita, 2013).

Penderita jerawat memiliki kadar androgen serum lebih tinggi dibandingkan dengan orang normal,meskipun kadar androgen serum penderita jerawat masih di dalam batas normal (Movita, 2013).

Bakteri penyebab jerawat antara lain Propionibacterium acnes, dan Staphylococcus epidermis. Propionibacteruim acnes merupakan flora normal dari kelenjar pilosebaseus kulit manusia, bakteri ini menyebabkan jerawat dengan menghasilkan lipase yang memecahkan asam lemak bebas dari lipid kulit. Asam lemak ini dapat mengakibatkan inflamasi jaringan ketika berhubungan dengan sistem imun dan mendukung terjadinya jerawat. Bakteri ini termasuk tipe bakteri anaerob gram positif yang toleran terhadap udara (Brook et al., 2005; Karyn, 2011).

Salah satu tanaman yang biasa digunakan sebagai obat jerawat adalah buah pare (Momordica charantia L) .Buah pare
(Momordica charantia L) mengandung Senyawa yang terdapat dalam daging buah pare meliputi : alkaloid,flavonoid, polifenol, steroid / triterpenoid (Oktaviana Rifka, 2012). Penyebab jerawat sangat banyak antara lain, genetic atau keturunan, hormon ,stress, kosmetik, faktor lingkungan, gesekan pada kulit, pijatan atau sentuhan pada jerawat, dan juga karena bakteri Propionibacterium acnes (Nurmalina \& Valley, 2011).

Buah pare (Momordica charantia L.) terhadap Eschericia coli dan staphylococcus aureus menunjukan hasil bahwa adanya golongan senyawa kimia dalam ekstrak buah pare yang mempunyai aktivitas antibakteri yaitu senyawa golongan terpenoid (Wibowo, 2015).

Tujuan dari penelitian ini adalah menentukan aktivitas ekstrak buah pare terhadap pertumbuhan Propionibacterium acnes. Manfaat dari penelitian ini adalah memberikan informasi kepada masyarakat mengenai khasiat ekstrak buah pare terhadap pertumbuhan Propionibacterium acnes dan sebagai referensi untuk penelitian selanjutnya.

\section{METODE PENELITIAN}

Penelitian ini merupakan penelitian jenis eksperimental laboratorium dengan melakukan serangkaian penelitian untuk 
menentukan aktivitas antibakteri ekstrak buah pare (Momordica charantia L.) terhadap pertumbuhan Propionibacterium acnes. Penelitian ini dilakukan pada bulan April 2017 di Laboratorium Mikrobiologi Jurusan Farmasi Politeknik Kesehatan Makassar.

Bahan uji pada penelitian adalah Buah Pare yang di peroleh dari Kota Makassar dan sampel uji pada penelitian ini adalah biakan murni Propionibacterium acnes Yang berasal dari Lab Mikrobiologi Farmasi Politeknik Kesehatan Makassar.

Adapun alat yang digunakan yaitu Autoklaf, Timbangan Analitik, Oven, Batang Pengaduk dan Cawan Petri. Sedangkan bahan yang digunakan yaitu Air suling,nMedium Nutrient Agar (NA), Buah Pare (Momordica charantia L)., Paper Disk dan Etanol 96\%.

\section{Prosedur Kerja}

Alat yang akan digunakan di sterilkan terlebih dahulu. Buah pare yang telah dipotongpotong kecil dan dikeringkan dimasukan dalam toples sebanyak 511,35 g kemudian dimaserasi selama 5 hari hingga diperoleh ekstrak kental buah pare.

Bakteri Propionibactreium acnes diremajakan kemudian disuspensikan dan diulas ke atas media NA diadaptasikan kurang lebih 15 menit, paper disk direndam dalam ekstrak buah pare dengan masing-masing konsentrasi $2,5 \%$, $5 \%, 10 \%$, control positif dan control negatif selama kurang lebih 15 menit. Diambil mengunakan pinset diletakan dipermukaan media NA, diinkubasikan pada suhu $37^{0} \mathrm{C}$ selama 1 x 24 jam.

\section{Pengamatan dan Pengukuran Diameter Hambatan}

Pengamatan dan pengukuran diameter hambatan dilakukan dengan mengunakan jangka sorong setelah diinokulasi selama 1x24 jam.

\section{Pengumpulan dan Pengolahan Data Zona Hambat}

Data yang diperoleh dari pengukuran diameter zona hambatan dianalisis secara statistik dengan mengunakan SPSS.

\section{Penarikan kesimpulan}

Kesimpulan diambil berdasarkan hasil pengolahan data yang telah dilakukan.

\section{HASIL}

Dari penelitian ini diperoleh hasil untuk kontrol positif diameter hambat rata-rata adalah $27 \mathrm{~mm}$, untuk kontrol negatif diameter hambat rata-rata adalah $0 \mathrm{~mm}$, untuk ekstrak buah pare konsentrasi $2,5 \%$ diamaeter hambat rata-rata adalah $11,6 \mathrm{~mm}$, untuk ekstrak buah pare konsentrasi $5 \%$ diameter hambat rata-rata adalah $12,3 \mathrm{~mm}$ dan untuk ekstrak buah pare konsentrasi $10 \%$ diameter hambat rata-rata adalah 13,6 mm.

\section{PEMBAHASAN}

Penelitian ini bertujuan untuk menetukan Aktivitas Ekstrak Buah Pare (momordica Charantia L.) Terhadap pertumbuhan Propionibacterum acnes dengan melihat zona hambat pada setiap konsentrasi.

Pada penelitian ini metode yang digunakan untuk mengekstraksi atau menarik zat aktif dari sampel Ekstrak buah pare yaitu metode maserasi. Maserasi adalah salah satu jenis metode ekstraksi dengan sistem tanpa pemanasan atau dikenal dengan istilah ekstraksi dingin, jadi pada metode ini pelarut dan sampel tidak mengalami pemanasan sama sekali. Maserasi dilakukan dengan cara merendam serbuk simplisia dalam cairan penyari. Jadi maserasi merupakan cara ekstraksi yang paling sederhana dengan cara merendam serbuk simplisia menggunakan pelarut yang sesuai dan tanpa pemanasan. Pelarut yang di pakai adalah etanol $96 \%$. Mekanisme kerja etanol $96 \%$ yaitu dengan menembus dinding sel dan masuk kedalam rongga sel yang mengandung zat aktif akan larut (warna larutan akan menjadi hijau kehitaman karena adanya perbedaan konsentrasi antara larutan zat aktif di dalam sel dengan yang diluar sel, maka larutan yang pekat didesak keluar dalam waktu 2-5 hari. Menggunakan pelarut etanol $96 \%$ yaitu karena etanol $96 \%$ dapat melarutkan zat aktif yang bersifat polar, non polar dari dalam simplisia.

Ekstrak buah pare yang digunakan dibuat dengan konsentrasi berbeda-beda dari konsentrasi 2,5\%, konsentrasi $5 \%$ dan konsentrasi $10 \%$. Setelah dilakukan penelitian mengenai uji aktivitas ekstrak buah pare terhadap pertumbuhan Propionibacterium acnes maka diperoleh hasil yang positif dengan terlihatnya adanya zona hambatan yang transparan dan melingkar disekitar paper disk. Pengukuran yang dilakukan dengan mengunakan alat ukur jangka sorong diperoleh diameter hambatan rata-rata pada setiap konsentrasi.konsentrasi 2,5\% sebesar 11,6 
$\mathrm{mm}$, konsentrasi $5 \%$ sebesar $12,3 \mathrm{~mm}$ dan konsentrasi 10\% 13,6 mm. Diameter hambatan rata-rata dari ekstrak buah pare yang diperoleh sesuai hasil pengamatan pada konsentrasi $10 \% \mathrm{~b} / \mathrm{v}$ lebih besar dibanding dengan konsentrasi $5 \% \mathrm{~b} / \mathrm{v}$ dan $2,5 \% \mathrm{~b} / \mathrm{v}$, begitu pula halnya dengan diameter hambatan pada konsentrasi $5 \% \mathrm{~b} / \mathrm{v}$ lebih besar dibandingkan dengan konsentrasi 2,5\%b/v. Hal ini menunjukkan bahwa semakin besar konsentrasi zat aktif maka semakin besar pula diameter zona hambat yang diperoleh.

$$
\text { Dari hasil perhitungan spss }
$$

menunjukan data yang diperoleh tidak homogeny dengan Nilai $\mathrm{p}=0,004<0,05$. Maka diperoleh juga tidak terdistribusi nomal yaitu diperoleh hasil $0,000<0,05$ maka dilanjutkan dengan tes non parametrik test dimana hasil tes non parametric test menunjukan signifikan pada hasil $0,009<0,05$.Sehingga pada penelitian ini dapat diketahui bahwa buah pare (Momordicacharantia L) mempunyai aktivitas terhadap pertumbuhan propionibacterium acnes dengan konsentrasi tinggi. Semakin besar konsentrasi yang dipakai maka semakin besar aktivitasnya. Daun pare mengandung zat aktif yang bersifat sebagai anti mikroba yaitu flavonoid. Selain itu, kandungan kimia daun pare adalah alkaloid ,saponin, triterponoid, steroid glikosida. Mekanisme kerjanya sebagai antibakteri yaitu dengan membentuk kompleks dengan protein ekstra seluler dan terlarut dengan dinding mikroba.Kemungkinan lainnya adalah flavonoid berperan secara langsung dengan mengganggu fungsi sel mikroorganisme dan penghambatan siklus sel mikroba.

\section{KESIMPULAN}

Berdasarkan hasil penelitian, maka dapat ditarik kesimpulan bahwa ekstrak buah pare (Momordica charantia L.) mempunyai aktivitas terhadap pertumbuhan Propionibacterium acnes. Hal ini ditunjukkan dengan hasil pengamatan yang menunjukkan diameter hambatan rata-rata untuk konsentrasi $10 \% \quad 13,6$ mm, untuk konsentrasi $5 \quad \% \quad 12,3 \quad \mathrm{~mm}$ dan untuk konsentrasi $2,5 \% \quad 11,6 \mathrm{~mm}$, walaupun diameter hambatan rata-rata yang diperoleh masih di bawah kontrol positif.

\section{SARAN}

Berdasarkan hasil penelitian yang dilakukan maka disarankan untuk peneliti selanjutnya membuat formulasi dari ekstrak buah pare menjadi satu sedian yang dapat menghambat pertumbuhan bakteri

Propionibacterium acnes.

\section{DAFTAR PUSTAKA}

Cannon, Joseph P, Wiliam D. Perreault, Jerome McCarthy. 2013. Pemasaran Dasar Edisi 16 Pendekatan Manajerial Global Buku 2, Jakarta: Penerbit Salemba Empat.

Darmadi, 2008. Infeksi Nosokomial : Problematika dan Pengendaliannya.Jakarta: Salemba Medika

Kristiawan. 2011. Morfologi dan Fisiologi Tumbuhan.Universitas Muhammadiah Surakarta.

Tri Cahyo Wibowo. 2015. Uji aktivitas ekstrak buah pare terhadap pertumbuhan Eschericia coli dan staphylococcus aureus.Fakultas Farmasi Universitas Muhammadiyah Surakarta

Herwowono. 2012 . Fakta tentang jerawat, (online)(http://www/619marz.blogspot.co.i d/2012/08/faktor-tentang-jerawat.html), diakses 15 januari 2017.

Multazam,M. 2012. Fakta tentang jerawat, (online)(http://www/619marz.blogspot.co.i d/2012/08/faktortentangjerawat.html), diakses 15 januari 2017.

Movita, T. 2013. Acne Vulgaris. Continuing Medical Education, 40(4), 269-272.

Nurmaina, K. 2014. Motivasi Berprestasi Mahasiswa Penyandang Tunadaksa.. Universitas Islam Negeri Sunan Ampel Surabaya.

Oktaviana Rif. 2012. "Uji Banding Efektivitas Ekstrak Buah Pare Belut (Trichosanthes Anguina Linn) Dengan Zink Pyrithione 1\% Terhadap Pertumbuhan Pityrosporum Ovale Pada Penderita Berketombe “" Program Pendidikan Sarjana Kedokteran Fakultas Kedokteran Univrsitan Diponegoro. Semarang.ka

Pramasanti, T, A. 2011. Uraian Propionibacterium Acnes. [Online]. Tesedia http://mikrobia.files.wordpress.com/2011/tr 
i-asih-pramasanti-078114019. pdf November 2016].

Tjitrosoepomo. 2010. Gembong. Taksonomi Tumbuhan. Gadja Mada Universitas Press, Yogyakarta.

Satria, P.W. 2015. Kitab Herbal Nusantara : Aneka Resep \& Ramuan Tanaman Obat Untuk Berbagai Gangguan Kesehatan. Yogyakarta : KATAHATI

SilvyA. 2012. Adsorbsi, Emulsifikasi dan antibakteri Ekstrak Daun Pare (Momordicach arantia L.). Bogor : Fakultas MIPA, Institut Pertanian Bogor

Suyowinito, M. 2013. Pemulihan Tanaman Secara Intro Vitro. Kanisius.Yogyakarta

Utami, P.R.Putri. 2015. Uji Daya Hambat Perasan Buah Jeruk Nipis (Citrus aurantifolia) Terhadap Pertumbuhan Propionibacterium acnes. Jurusan
Farmasi. Makassar: Politeknik Kesehatan Makassar.

Wasitaatmadja, S. 2008. Ilmu Penyakit Kulit dan Kelamin. jakarta: Balai Penerbit FKUI.

Waluyo, I. 2009. Tehnik Metode Dasar Mikrobiologi. Universitas Muhammadiyah Malang : Malang

Wikipedia. 2017. Petani. Diakses 2 januari 2017 Pukul 15.03 WIB, dari http://id.wikipedia.org.

Yuniawati ,d. 2012. Uraian Dan Mekanisme Obat Clindamisyn. Jakarta: Balai Penerbit FKUI.

Yuda. 2013. Kandungan Dan Kegunaan Buah Pare.UIN Malang

Tabel 1. Hasil pengukuran Diameter hambatan Ekstrak buah pare

\begin{tabular}{c|c|c|c|c|c}
\hline \multirow{2}{*}{ Replikasi } & \multicolumn{2}{|c|}{ Kontrol (mm) } & \multicolumn{3}{c}{ Konsentrasi } \\
\cline { 2 - 6 } & Positif & Negatif & $2,5 \%$ & $5 \%$ & $\mathbf{1 0 \%}$ \\
\hline \multirow{2}{*}{ I } & 27 & 0 & 11 & 12 & $\mathbf{1 3}$ \\
& 27 & 0 & 11 & 12 & $\mathbf{1 4}$ \\
\hline III & 27 & 0 & 11 & 12 & $\mathbf{1 3}$ \\
& 27 & 0 & 11 & 12 & 12 \\
\hline Total & 27 & 0 & 11 & 12 & $\mathbf{1 4}$ \\
& 27 & 0 & 11 & 37 & $\mathbf{4 1}$ \\
\hline Rata-rata & 81 & 0 & 35 & $\mathbf{1 2 , 3}$ & $\mathbf{1 3 , 6}$ \\
\hline
\end{tabular}




\section{MEDIA FARMASI}

POLITEKNIK KESEHATAN MAKASSAR

Penasehat

Penanggung Jawab

Dewan Redaksi

Ketua

Anggota

Mitra Bestari

Alamat Redaksi
: Direktur Politeknik Kesehatan Kemenkes Makassar

: Ketua Jurusan Farmasi Politeknik Kesehatan

Kemenkes Makassar

: $\quad$ Santi Sinala, S,Si, M.Si, Apt

: Hendra Stevani, S.Si, M.Kes, Apt

Sisilia Teresia Rosmala Dewi, S.Si, M.Kes, Apt

Muli Sukmawaty, S.Farm, Apt

Muhammad Riswan, S.Kom

: $\quad$ Dr. Islamudin Ahmad, M.Si,Apt (Universitas Mulawarman)

DR. Rusli, Sp.FRS, Apt

DR. Hj. Nurisyah, M.Si, Apt (Poltekkes Makassar)

DR. Sesilia Rante Pakadang, M.Si, Apt (Poltekkes Makassar)

DR. H. Asyhari Asyikin, S.Farm, M.Kes (Poltekkes Makassar)

: Jurusan Farmasi

Politeknik Kesehatan Kementerian Kesehatan Makassar

J1. Baji Gau No.10 Makassar

Telp. 0411-854021, 830883 Fax. 0411-830883

Kode pos 90134

Website :

http://journal.poltekkes-mks.ac.id/ojs2/index.php/mediafarmasi/index 


\section{EDITORIAL}

Pembaca yang budiman, ucapan syukur Alhamdulillah kami panjatkan ke hadirat Tuhan Yang Maha Kuasa karena berkat rahmat dan anugerahNya sehingga penerbitan Vol. XIV No.2, Oktober 2018 MEDIA FARMASI POLITEKNIK KESEHATAN MAKASSAR dapat terlaksana dan telah mendapat legalitas sebagai media resmi dari Lembaga Ilmu Pengetahuan Indonesia (LIPI) dengan nomor penerbitan pISSN No. 0216-2083 dan e-ISSN No. 2622-0962.

Media Farmasi Politeknik Kesehatan Makassar merupakan suatu wadah dalam menampung aspirasi ilmiah sehingga dapat menggugah motivasi dan inovasi dari dosen di lingkup Jurusan Farmasi Politeknik Kesehatan Makassar serta artikel dari simpatisan untuk melakukan kajian ilmiah.

Media Farmasi Politeknik Kesehatan Makassar diterbitkan 2 kali dalam setahun yaitu pada bulan April dan Oktober. Sebagai majalah ilmiah, Media Farmasi mengembangkan misi dalam memajukan ilmu pengetahuan dan teknologi kesehatan khususnya di bidang farmasi

Akhirnya redaksi sangat berharap bahwa semua artikel yang disajikan dalam edisi ini dapat memberi apresiasi keilmuan di bidang kesehatan bagi kita semua. Oleh karena itu kritikan dan saran sangat kami harapkan demi kesempurnaan edisi-edisi selanjutnya.

Selamat membaca

Makassar, Oktober 2018

Redaksi 


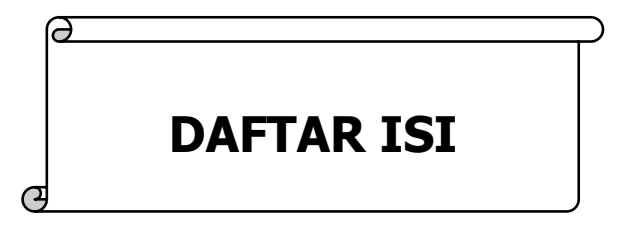

Pengaruh Pemberian Ekstrak Etanol Daun Afrika (Vernonia amygdalina

Del.) terhadap Kadar Asam Urat Darah Mencit Jantan (Mus musculus)

Jumain, Asmawati, Rini Karnita

Efektivitas Pemberian Rebusan Daun Pandan Wangi (Pandanus

Amaryllifolius Roxb.) terhadap Penurunan Kadar Glukosa Darah

Mencit (Mus musculus)

Amran Nur, Desi Reski Fajar, Musdalifah

Uji Efek Analgetik Infusa Jahe (Zingiber officinale Roscoe) terhadap Hewan Uji Mencit Jantan (Mus musculus)

Sisilia T. Rosmala Dewi, Hiany Salim.

Pengaruh Usia dan Tingkat Pendidikan terhadap Pemahaman Pasien

Setelah Pelayanan Informasi Obat di Puskesmas Makale Kabupaten

Tana Toraja Tahun 2018

Estherina Allo Payung, Septyani Mambela

Uji Daya Hambat Antibiotika Terhadap Bakteri Penyebab Infeksi

Saluran Kemih Di Rumah Sakit Salewangang Maros

Andi Dian Aulia Saudi, Rusdy

Uji Aktivitas Ekstrak Buah Pare (Momordica charantia L) terhadap Pertumbuhan Propionibacterium acnes

Dwi Rachmawaty Daswi, Asmawati

Analisis Kandungan Merkuri (Hg) pada Sediaan Krim Pemutih yang Beredar di Pasaran Kota Makassar dengan Menggunakan Metode Spektrofotometri Serapan Atom

Dedy Ma'ruf, Andi Asmawati, Ririn Muliana

Penentuan Total Polifenol Ekstrak Etanol Kulit Kecapi (Sandoricum koetjape) dari Lamasi Kabupaten Luwu

Santi Sinala, Minati, Alfrida Monica Salasa

Uji Potensi Antimikroba Hasil Fraksinasi Ekstrak Daun Kecombrang (Etlingera elatior) terhadap Candida albicans Penyebab Keputihan Pada Ibu Hamil

St. Ratnah, Alfrida Monica Salasa, H. Ismail Ibrahim 
Efek Konseling terhadap Tingkat Pengetahuan Ibu pada Terapi

Diare Balita

Khaerani, Surya Ningsi, Andi Try Resti Fauziah Sahib

Uji Daya Hambat Daun Tammate (Lannea coromandelica) terhadap

Bakteri Propionibacterium acnes dan Escherichia coli

Nurlaela, Abd.Karim, Taufiq Dalming

Efektivitas Ekstrak Air Buah Belimbing Wuluh (Averrhoa bilimbi)

Terhadap Pertumbuhan Propionibacterium acnes

Arisanty, Rara Puspa Dewi

Aktivitas Perasan Biji Pinang (Areca catechu L.) terhadap Pertumbuhan

Streptococcus mutans

Ikke Nurjanna, Hendra Stevani, Ratnasari Dewi

Evaluasi Tingkat Kepuasaan Pasien terhadap Pelayanan Kefarmasin di Depo IGD

Rumah Sakit TK II Pelamonia Makassar

Rahmawati, Desi Reski Fajar, Ira Widya Sari

78

Analisis Lama Waktu Tunggu Pelayanan Resep di Apotek BPJS

Rawat Jalan Rumah Sakit Pelamonia

Veronika Dampung, Ita Purnama Sari, Citra Rahayu, Rusli 